\title{
Pengaruh Konsentrasi Oksidator pada Proses Hidroksilasi Minyak Jarak (Castor Oil) Dengan atau Tanpa Proteksi Gugus Hidroksi
}

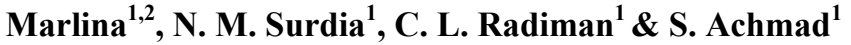 \\ ${ }^{1}$ Departemen Kimia, Institut Teknologi Bandung, Ganesha 10 Bandung \\ 2 Jurusan Kimia, Universitas Syiah Kuala, Darussalam-Banda Aceh \\ E-mail: marlina_rachman@yahoo.com
}

\begin{abstract}
Sari. Minyak jarak telah dihasilkan dari biji pohon jarak jenis Ricinus communis L., yang termasuk famili Euphorbiaceae. Minyak yang diperoleh per gram biji jarak adalah sebanyak 45 - $52 \%$ dengan kualitas yang lebih murni dibandingkan dengan standard yang dihasilkan oleh The Association of Official Analytical Chemistry (AOAC). Hasil analisa menunjukkan bahwa komponen utama dalam minyak jarak adalah asam oleat, palmitat, dan resinoleat. Proses proteksi gugus hidroksi minyak jarak dengan cara asetilasi berlangsung baik, hal ini ditunjukkan oleh naiknya bilangan iod dan turunnya bilangan hidroksi, serta terjadinya perubahan struktur minyak seperti yang ditunjukkan oleh spektrum infra merah. Proses oksidasi terjadi lebih efektif pada minyak yang terproteksi secara asetilasi dari pada minyak tanpa proteksi. Kelebihan konsentrasi oksidator mengubah hasil oksidasi (gugus $\mathrm{OH}$ ) menjadi aldehid dan asam karboksilat. Kondisi optimum proses hidroksilasi dicapai pada konsentrasi oksidator $15 \%$, dengan nilai bilangan iod 33,093 mg/g dan bilangan hidroksi $1280.438 \mathrm{mg} / \mathrm{g}$.
\end{abstract}

Kata kunci: asetilasi; bilangan hidroksi; bilangan iod; isolasi; minyak jarak; oksidasi; proteksi; sokletasi.

Abstract. Oil is derived from the bean of castor plant ricinus communis $l$, belonging to euphorbiaceae family. Oil rendement per gram of castor bean is 45 - $48 \%$ with hight pure product and better than standard resulted by The Association of Official Analytical Chemistry (AOAC). The main components in castor oil are oleic, palmitic and resinoleic acid. Protection process by acetylation occurs well on hydroxyl group of castor oil, indicated by increasing of iodine number and decreasing of hydroxyl number. Oxidation process is more efective on protected oil than non protected oil. The excess of oxidator concentration changed the product to be aldehide and carboxylic acid. Optimum condition was reached when oxidator concentration was $15 \%$, with hydroxyl value of $1280.438 \mathrm{mg} / \mathrm{g}$ and iodine number of $33.093 \mathrm{mg} / \mathrm{g}$.

Keywords: acetylation; hydroxyl value; iodine number; isolation; castor oil; oxidation; protection; soxhletation. 


\section{Pendahuluan}

Minyak jarak didapatkan dari biji pohon jarak Ricinus communis L., yang termasuk famili Euphorbiaceae. Pohon jarak terdapat hampir di semua negara tropis dan sub tropis. Pohon jarak bervariasi dalam ukuran, bentuk dan warna, begitu pula dengan bijinya ${ }^{[1,2]}$.

Minyak jarak digunakan sebagai bahan dasar industri, pelarut, pelumas, pewarna, resin, pemlastis (plasticizer), furnis, tinta, adesif, laminating dan pelapis ${ }^{[1,2]}$.

Minyak jarak juga dikenal sebagai ricinus oil, oil of Palma Christi, tangantangan oil, and neoloid. Minyak jarak merupakan trigliserida dari berbagai asam lemak yang terdiri atas: $87 \%$ risinoleat, $7 \%$ oleat, $3 \%$ linoleat, $2 \%$ palmitat, $1 \%$ stearat, dan sejumlah kecil dihidroksistearat ${ }^{[1,2]}$.

Asam resinoleat atau asam risinolein merupakan asam yang paling banyak terdapat dalam minyak jarak, mempunyai struktur molekul asam cis-12hidroksioktadeka-9-enoat $\quad\left(\mathrm{CH}_{3}\left(\mathrm{CH}_{2}\right)_{5} \mathrm{CH}(\mathrm{OH}) \mathrm{CH}_{2} \mathrm{CH}=\mathrm{CH}\left(\mathrm{CH}_{2}\right)_{7} \mathrm{COOH}\right)$, dengan satu gugus fungsi hidroksi ${ }^{[1]}$.

Gugus ester, ikatan rangkap dan hidroksi dari minyak jarak dapat bereaksi menghasilkan bahan-bahan yang berguna. Struktur kimia minyak jarak serta gugus-gugus fungsinya dapat dilihat pada Gambar $1^{[3,4]}$.

Proses hidroksilasi bertujuan untuk menambah gugus hidroksi ke dalam molekul dengan cara memecah ikatan rangkap. Salah satu caranya adalah dengan proses oksidasi menggunakan oksidator dengan dan tanpa bantuan katalis ${ }^{[5,6,7]}$. Sebelum dilakukan oksidasi terhadap ikatan rangkap, gugus hidroksi yang ada dalam minyak jarak harus diproteksi terlebih dahulu untuk mencegah reaksi samping yaitu teroksidasinya gugus hidroksi yang terkandung dalam minyak jarak.

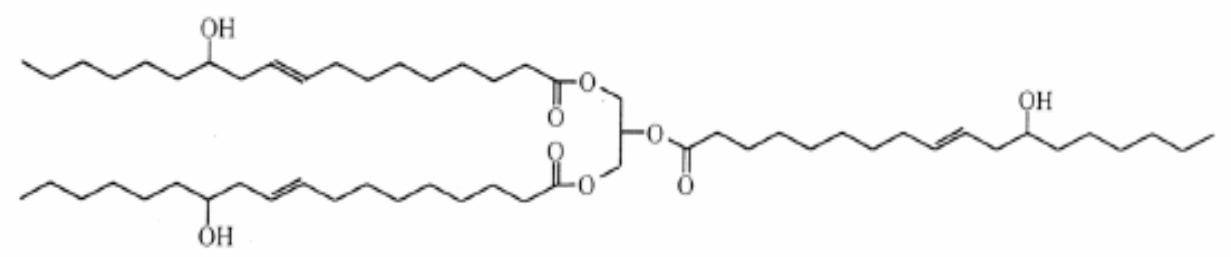

Gambar 1 Struktur minyak jarak serta gugus-gugus fungsinya. 
Proses proteksi gugus hidroksi $(-\mathrm{OH})$ atau alkohol akan mengubah gugus $-\mathrm{OH}$ menjadi ester atau eter dengan menggunakan reagen spesifik ${ }^{[5,6,7,8]}$.

\subsection{Gugus Hidroksi Berubah Menjadi Ester (RCOOR)}

Ada beberapa metoda yang dapat dilakukan untuk memproteksi gugus $-\mathrm{OH}$, satu diantaranya adalah dengan proses asetilasi, di mana gugus asetil dimasukkan ke gugus $-\mathrm{OH}$ untuk membentuk ester.

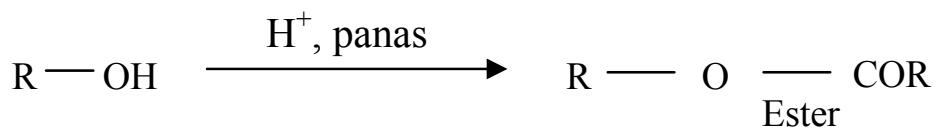

$$
\begin{aligned}
& \begin{array}{cc}
\mathrm{O} & \mathrm{O} \\
\mathrm{R}-\mathrm{OH}+\mathrm{R}-\mathrm{C}-\mathrm{O}-\mathrm{C}-\mathrm{CH}_{3} \stackrel{\mathrm{H}^{+} \text {, panas }}{\longrightarrow} \mathrm{R}-\mathrm{O}-\mathrm{COCH}_{3}
\end{array}
\end{aligned}
$$

\subsection{Gugus Hidroksi Berubah Menjadi Eter (ROR)}

Suatu alkohol dapat diubah menjadi eter dengan proses metilasi, contohnya.:

$$
\mathrm{R} \longrightarrow \mathrm{OH} \underset{\mathrm{Ag}_{2} \mathrm{O}, \text { basa }}{\stackrel{\mathrm{CH}_{3} \mathrm{I}}{\longrightarrow}} \mathrm{R}-\mathrm{O}-\mathrm{CH}_{3}
$$

L.S. Kiong dan John H.P.T memproteksi gugus hidroksi asam anakardat menggunakan metilsulfat dan benzen yang mengandung kalium karbonat pada pembuatan urushiol, di mana gugus hidroksi dari asam diubah menjadi suatu eter. Gugus hidroksi dari ester atau eter yang terbentuk di atas dapat diperoleh kembali dengan menggunakan larutan asam atau basa ${ }^{[9]}$. Kemudian pada tahun 2001 Demirtas I. melakukan proteksi terhadap gugus hidroksi dan sulfur menggunakan trityls ${ }^{[10]}$.

Kalium permanganat $\left(\mathrm{KMnO}_{4}\right)$ dapat mengoksidasi alkena menghasilkan reaksi cis-hidroksilasi. Sementara 1,2 diol dapat dihasilkan dari reaksi transhidroksilasi suatu alkena dengan produk antara epoksida dengan menggunakan kloroform atau diklorometana sebagai pelarut ${ }^{[5,6]}$.

Penentuan semua sifat fisik dan kimia dari minyak jarak sebelum dan setelah perlakuan didasarkan pada AOAC (Official Methods of Analysis) ${ }^{[11]}$.

Tujuan penelitian ini adalah mempelajari pengaruh konsentrasi oksidator $\left(\mathrm{KMnO}_{4}\right)$ terhadap sifat fisik dan kimia minyak jarak dengan atau tanpa proteksi gugus hidroksi dengan cara asetilasi. 


\section{Percobaan}

\subsection{Isolasi Minyak Jarak}

Minyak jarak dari biji pohon jarak yang berasal dari daerah Nangroe Aceh Darussalam diisolasi dengan cara sokletasi menggunakan $n$-heksan selama 3-5 jam. Minyak yang diperoleh kemudian dievaporasi untuk menghilangkan sisa pelarut dan uap air ${ }^{[8]}$.

\subsection{Proteksi Gugus Hidroksi Dengan Cara Asetilasi}

Ke dalam $25 \mathrm{~mL}$ sampel ditambahkan $6 \mathrm{~mL}$ asam asetat anhidrid dan $0,5 \mathrm{~mL}$ piridin, kemudian campuran yang diperoleh diaduk pada temperatur $20{ }^{\circ} \mathrm{C}$ selama 2 jam. Larutan yang diperoleh diekstraksi dengan menggunakan kloroform, kemudian fasa organik dievaporasi dengan menggunakan alat rotary evaporator sehingga diperoleh minyak kental sebagai produk utamanya ${ }^{[7]}$.

\subsection{Proses Oksidasi Minyak Jarak}

Pada proses hidroksilasi secara oksidasi, $25 \mathrm{~mL}$ sampel hasil proteksi atau sampel murni ditambahkan 2,5 mL larutan $\mathrm{KMnO}_{4}$ dalam suasana basa pada temperatur $25{ }^{\circ} \mathrm{C}$ dengan konsentrasi yang bervariasi yaitu dari $5 \%$ sampai 35 $\%$. Setelah diaduk selama 90 menit, dibiarkan selama 24 jam, kemudian disaring menggunakan kaca masir. Hasil yang diperoleh ditambahkan asam sulfat $5 \%$ sebanyak $10 \mathrm{~mL}$ sebagai bahan pelepas proteksi dan diekstrak menggunakan pelarut kloroform untuk memisahkan fasa air yang tersisa. Fasa organik berupa sampel teroksidasi ditambahkan $\mathrm{Na}_{2} \mathrm{SO}_{4}$, disaring, dan diuapkan serta dilakukan karakterisasi.

\subsection{Karakterisasi}

Karakterisasi sifat fisik-kimia minyak jarak yang dilakukan meliputi penentuan bilangan iod dan bilangan hidroksi, analisis struktur menggunakan alat spektrometer infra merah ( FTIR merk Perkin Elmer) dan spektrometer massakromatografi gas (GC-MS). Semua analisis didasarkan pada Official Methods of Analysis of AOAC International ${ }^{[11]}$.

\subsubsection{Penentuan Bilangan Iod Minyak}

Sampel ditimbang sekitar 0,3 - 0,4 gram, kemudian dimasukkan ke dalam Erlenmeyer. Sebanyak $10 \mathrm{~mL}$ kloroform dan $30 \mathrm{~mL}$ larutan Hanus ditambahkan ke dalam sampel. Larutan disimpan selama 30 menit ditempat gelap. Selanjutnya ditambahkan $10 \mathrm{~mL}$ larutan KI $15 \%$ dan $100 \mathrm{~mL}$ aquadest. Larutan dititrasi dengan menggunakan larutan natriumtiosulfat $0,1 \mathrm{~N}$ sampai terjadi perubahan warna kekuning-kuningan. Ditambahkan 1-2 mL larutan amilum dan ditritasi kembali dengan larutan natrium sulfat $0,1 \mathrm{~N}$ sampai warna berubah menjadi jernih. Dengan cara yang sama dilakukan terhadap larutan blanko. Bilangan iod ditentukan dengan persamaan: 


$$
\text { Bilangan Iod }=\frac{(b-a) \cdot N \cdot 12,69}{m}
$$

di mana:

$$
\begin{aligned}
& \mathrm{b}=\mathrm{mL} \text { natriumtiosulfat yang digunakan untuk menitrasi blanko } \\
& \mathrm{a}=\mathrm{mL} \text { natriun tiosulfat untuk menitrasi sampel } \\
& \mathrm{N}=\text { konsentrasi natrium tiosulfat } \\
& \mathrm{m}=\text { berat sampel }
\end{aligned}
$$

\subsubsection{Penentuan Bilangan Hidroksi}

Sebanyak $4 \mathrm{~mL}$ reagen asetilasi ditambahkan ke dalam 0,5 gram sampel, dipanaskan sampai suhu $98{ }^{\circ} \mathrm{C}$ selama 2 jam, kemudian didinginkan pada temperatur kamar. Sebanyak $6 \mathrm{~mL}$ aquadest ditambahkan ke dalam larutan, kemudian tutup dan dinding botol dibilas, dan didiamkan selama 24 jam. Indikator pp 1\% sebanyak 3-4 tetes ditambahkan ke dalam larutan dan larutan dititrasi dengan menggunakan larutan $\mathrm{KOH} 0,1 \mathrm{~N}$. Bilangan hidroksi $(-\mathrm{OH})$ ditentukan dengan persamaan:

$$
\text { Bilangan } \mathrm{OH}=\frac{(\mathrm{b}-\mathrm{a}) \cdot \mathrm{N} \cdot 56,1}{\mathrm{~m}}
$$

di mana:

$\mathrm{b}=\mathrm{mL} \mathrm{KOH}$ yang digunakan untuk menitrasi blanko

$\mathrm{a}=\mathrm{mL} \mathrm{KOH}$ untuk menitrasi sampel

$\mathrm{N}=$ konsentrasi $\mathrm{KOH}$

$\mathrm{m} \quad=$ berat sampel

\section{Diskusi}

\subsection{Sifat-sifat Fisiko-Kimia Minyak Jarak}

Minyak jarak dihasilkan melalui proses sokletasi biji jarak dengan menggunakan $n$-hexane sebagai pelarut, dan hasil yang diperoleh adalah sebesar $40-48 \%$.

Hasil karakterisasi terhadap sifat fisiko-kimia minyak dapat dilihat pada Tabel 1. Dari data tersebut tampak bahwa ada beberapa sifat seperti indek bias, berat jenis, dan bilangan asam yang berbeda dengan standar yang diberikan oleh AOAC. Hal ini disebabkan karena minyak tersebut berasal dari pohon yang tumbuh pada daerah yang berbeda, sehingga mengandung bahan-bahan yang berbeda pula. Di samping itu, cara pengolahan yang berbeda akan menghasilkan minyak dengan sifat-sifat dan kualitas yang berbeda. Dari hasil analisis ini dapat dikatakan bahwa minyak jarak yang dihasilkan dalam penelitian ini mempunyai 
kualitas yang lebih baik dari yang disyaratkan oleh standar AOAC, karena mempunyai bilangan asam yang rendah dan bilangan penyabunan yang tinggi.

\begin{tabular}{|l|c|}
\hline \multicolumn{1}{|c|}{ Sifat } & Nilai \\
\hline Indek Bias, $25^{\circ} / 25^{\circ}$ & 1.5886 \\
\hline Berat Jenis, $\mathrm{g} / \mathrm{mL}$ & 0.997 \\
\hline${\text { Titik Didih, }{ }^{\circ} \mathrm{C}}^{\circ}$ & 256 \\
\hline Bilangan Asam, $\mathrm{mg} / \mathrm{g}$ & 113.798 \\
\hline Bilangan Iod, $\mathrm{mg} / \mathrm{g}$ & 87,095 \\
\hline Bilangan Hidroksi, $\mathrm{mg} / \mathrm{g}$ & 162.176 \\
\hline Bilangan Penyabunan, $\mathrm{mg} / \mathrm{g}$ & 896,837 \\
\hline Bilangan Ester, $\mathrm{mg} / \mathrm{g}$ & 783.039 \\
\hline Putaran Optik, ${ }^{\circ}$ & $\mathrm{D} 8,6$ \\
\hline
\end{tabular}

Tabel 1 Karakterisasi sifat fisiko-kimia minyak jarak.

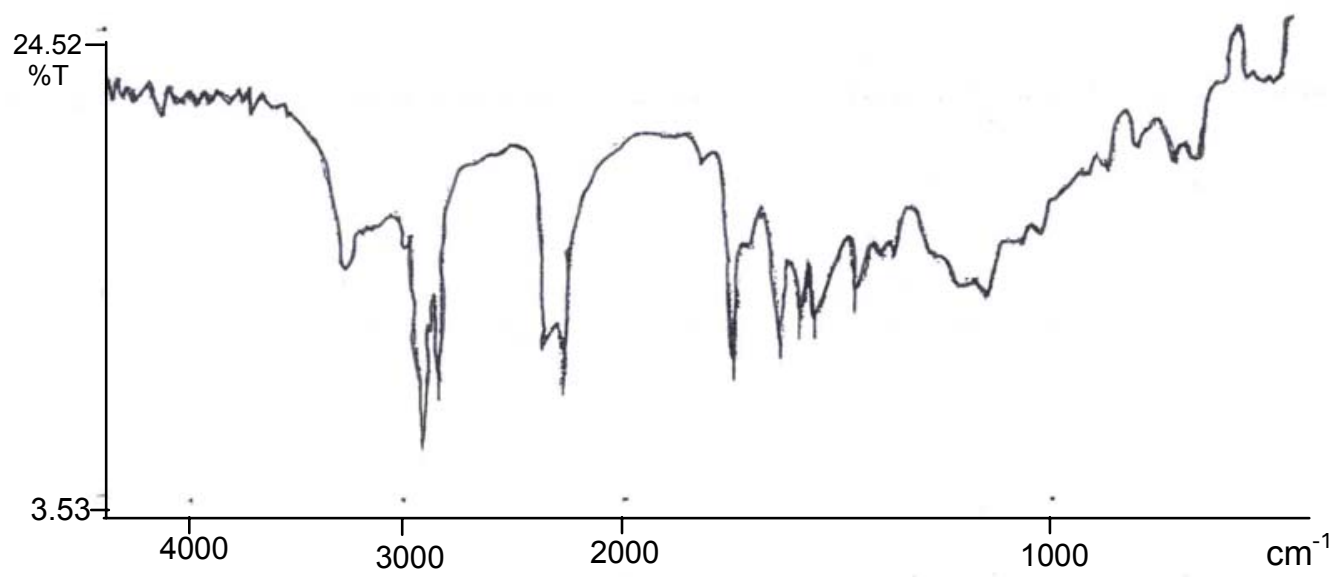

Gambar 2 Spektrum infra merah minyak jarak.

Gambar 2 menunjukkan spektrum infra merah minyak jarak hasil sokletasi. Pada spektrum tersebut terlihat adanya serapan yang lemah pada bilangan gelombang 3300-3400 $\mathrm{cm}^{-1}$, yaitu serapan spesifik untuk gugus hidroksi. Sebaliknya pada bilangan gelombang $1500-1600 \mathrm{~cm}^{-1}$ tampak adanya intensitas 
absorpsi yang tajam dari ikatan rangkap dalam minyak jarak. Dengan demikian minyak jarak sebelum perlakuan memiliki gugus - $\mathrm{OH}$ dan ikatan rangkap, dan serapan $-\mathrm{OH}$ lebih lemah dibandingkan dengan serapan ikatan rangkap.

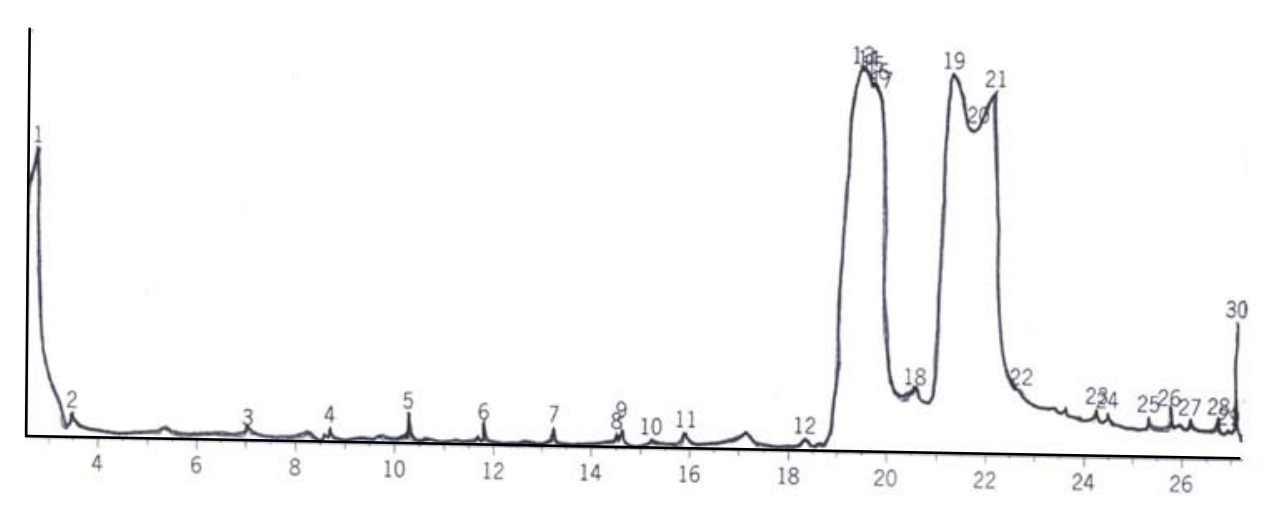

Gambar 3 Spektra massa minyak jarak.

Gambar 3 menunjukkan kromatogram minyak jarak hasil sokletasi yang dianalisa menggunakan alat khromatografi gas-spektroskopi masa (GC-MS). Hasil analisa memperlihatkan adanya puncak tertinggi terdapat pada waktu retensi 19.550 dan 21.258 detik yang merupakan asam-asam lemak bebas, seperti asam resinoleat, asam palmitat, asam linoleat dan asam oleat. Hal ini dapat dimengerti karena minyak jarak memang mengandung sebagian bahanbahan tersebut. Asam resinoleat yang merupakan komponen utama dalam minyak jarak seharusnya mempunyai jumlah yang besar yaitu $87 \%$, akan tetapi dalam penelitian ini rendemennya hanya sekitar 37\%.

\subsection{Proteksi Gugus Hidroksi}

Pada proses proteksi melalui asetilasi, bilangan iod, bilangan hidroksi dan struktur minyak jarak dapat dianalisa perubahannya selama perlakuan, karena ke tiga sifat ini berubah akibat pengaruh perubahan kimianya. Hasil analisa menunjukkan bahwa bilangan iod naik mencapai angka 96,277 mg/g, sedangkan bilangan hidroksi turun menjadi $109,35 \mathrm{mg} / \mathrm{g}$. Spektrum IR minyak jarak hasil proteksi asetilasi tampak pada Gambar 4. Dari gambar tersebut tampak bahwa serapan untuk gugus $\mathrm{OH}$ pada bilangan gelombang 3330-3400 $\mathrm{cm}^{-1}$ tidak ada, sedangkan serapan untuk ikatan rangkap $\mathrm{C}=\mathrm{C}$ pada bilangan gelombang 1500-1600 $\mathrm{cm}^{-1} 1$ terlihat jelas dan tajam. Dari hasil-hasil tersebut dapat dikatakan bahwa proses proteksi telah berjalan dengan baik. 


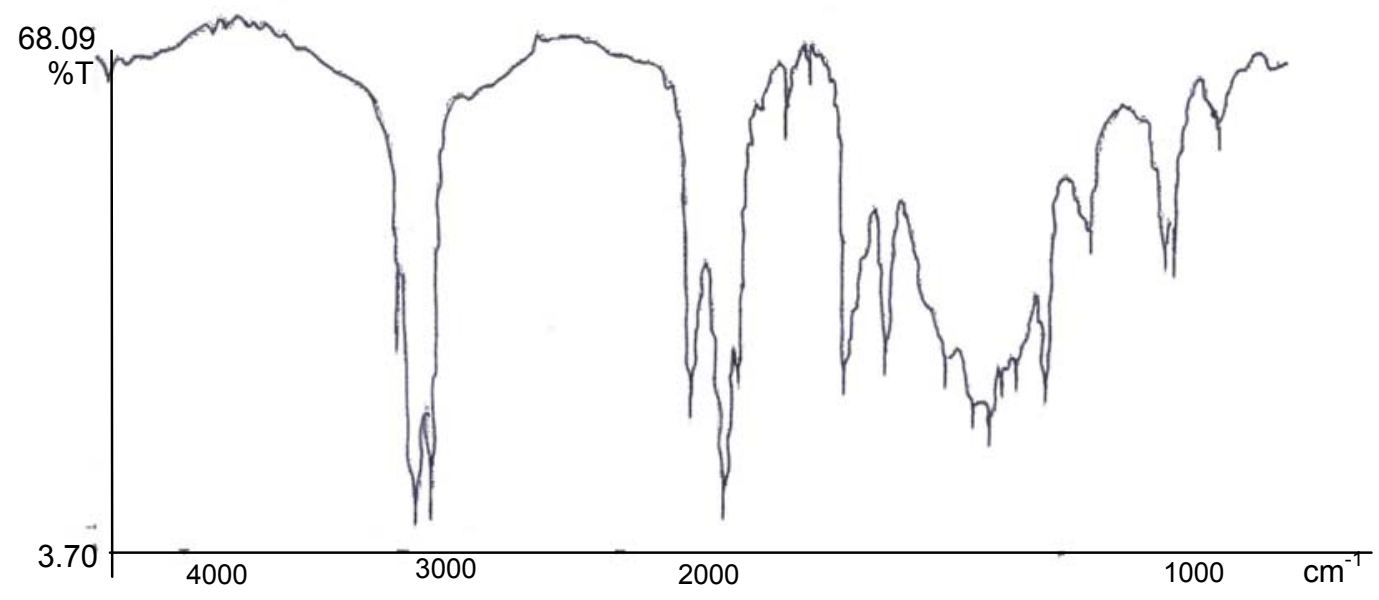

Gambar 4 Spektrum IR minyak jarak hasil proteksi dengan asetilasi.

\subsection{Proses Oksidasi}

Gambar 5 menunjukkan perubahan bilangan iod dari minyak jarak hasil oksidasi baik yang tidak terproteksi maupun yang terproteksi dengan cara asetilasi. Bilangan iod turun drastis dengan naiknya konsentrasi oksidator, dan cenderung konstan setelah dicapai nilai optimum.

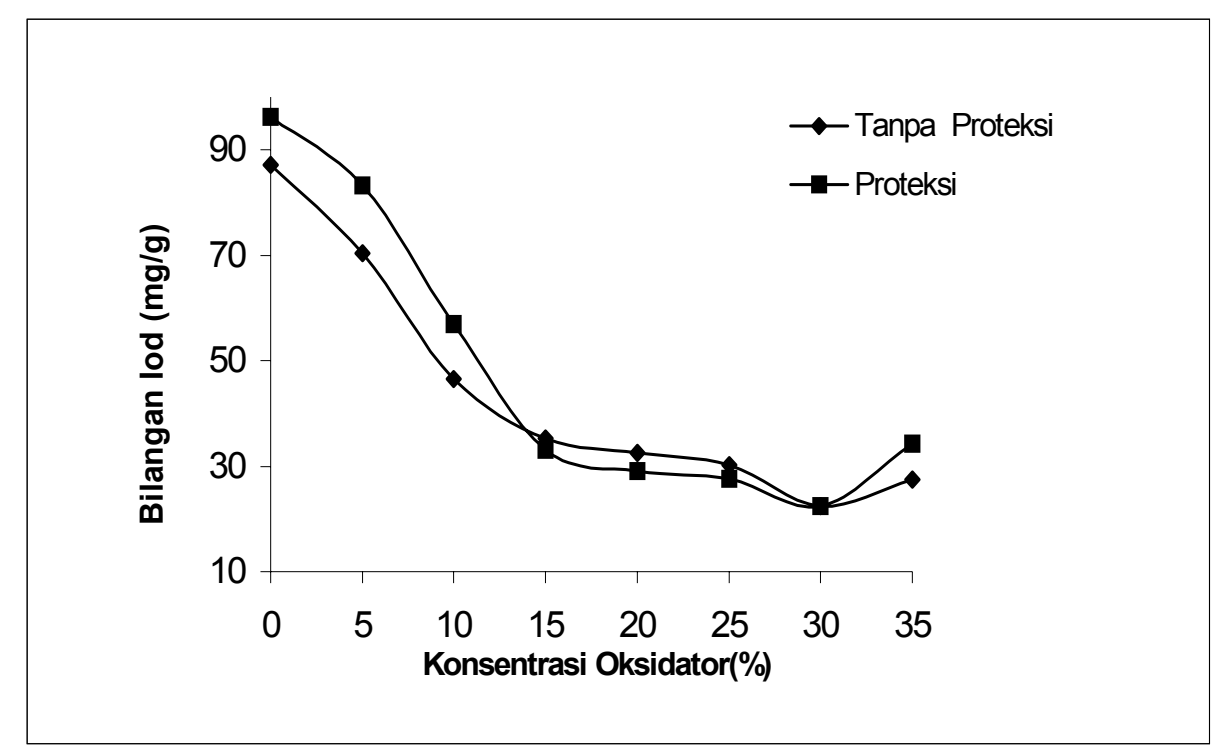

Gambar 5 Pengaruh konsentrasi oksidator terhadap bilangan iod minyak jarak. 
Analisa bilangan hidroksi yang tampak pada Gambar 6, terlihat semakin tinggi konsentrasi oksidator yang digunakan, bilangan hidroksi dari minyak terproteksi dan tanpa proteksi semakin besar dan hampir konstan setelah harga optimum telah dicapai. Fenomena ini dapat dijelaskan bahwa pada konsentrasi oksidator berlebih, hasil oksidasi (gugus -OH) akan membentuk produk baru yaitu aldehid, dan pada konsentrasi lebih tinggi senyawa ini akan berubah lagi menjadi senyawa lain yaitu asam karboksilat.

Kondisi terbaik didapat untuk minyak jarak yang terasetilasi, dan perubahan ikatan rangkap menjadi gugus hidroksi mencapai nilai maksimum pada saat konsentrasi oksidator yang digunakan $15 \%$, yang mana bilangan iod turun menjadi 33,093 mg/g dan bilangan hidroksi meningkat menjadi $1280,438 \mathrm{mg} / \mathrm{g}$. Hasil ini jauh lebih besar dibandingkan dengan hasil yang diperoleh untuk minyak tanpa asetilasi terlebih dahulu.

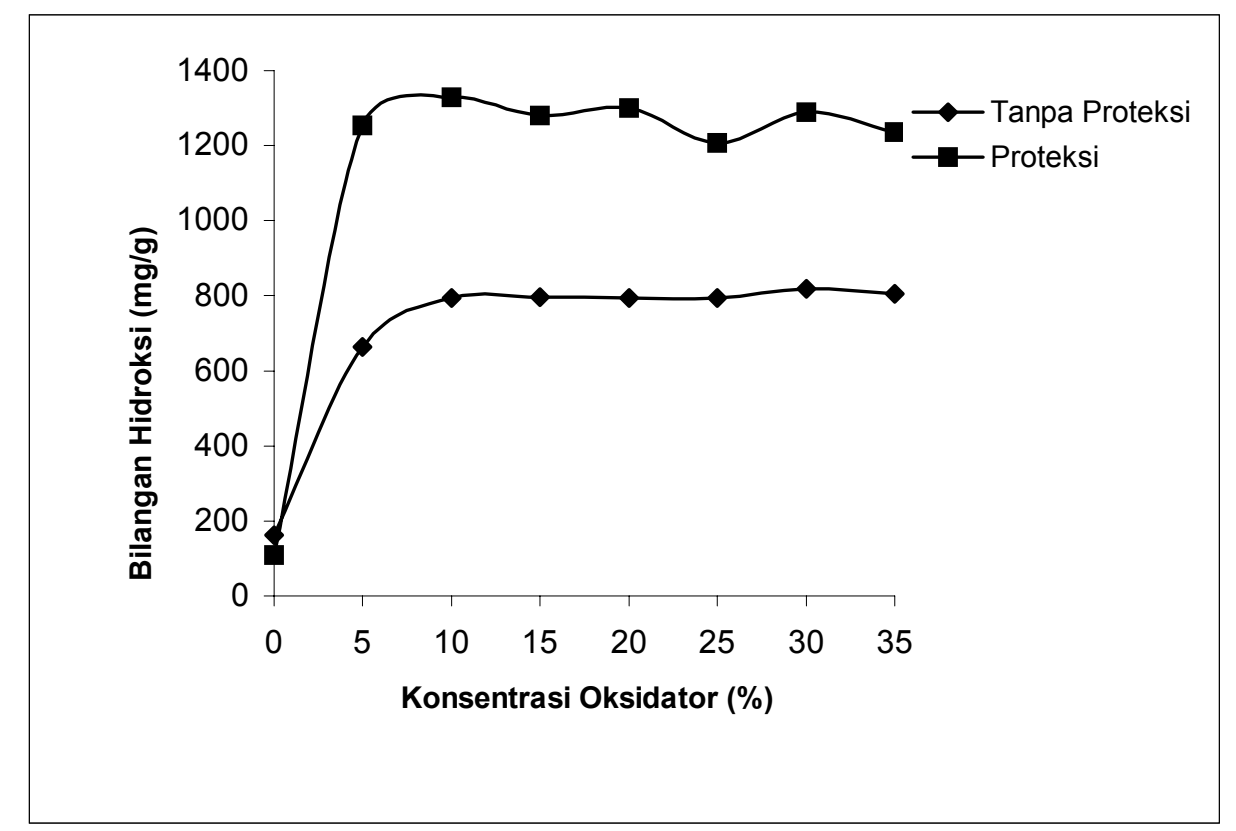

Gambar 6 Pengaruh konsentrasi oksidator terhadap bilangan hidroksi minyak.

Gambar 7 merupakan spektrum infra merah minyak hasil oksidasi baik untuk minyak terasetilasi maupun tidak. Gambar 7a adalah spektrum IR minyak teroksidasi tanpa asetilasi terlebih dahulu, terlihat serapan untuk gugus $-\mathrm{OH}$ sangat lemah. Sementara pada Gambar $7 \mathrm{~b}$ memperlihatkan adanya serapan untuk gugus $-\mathrm{OH}$ yang lebar dan tajam, dan serapan yang lemah untuk ikatan rangkap dari minyak jarak hasil oksidasi melalui proteksi dengan asetilasi. 

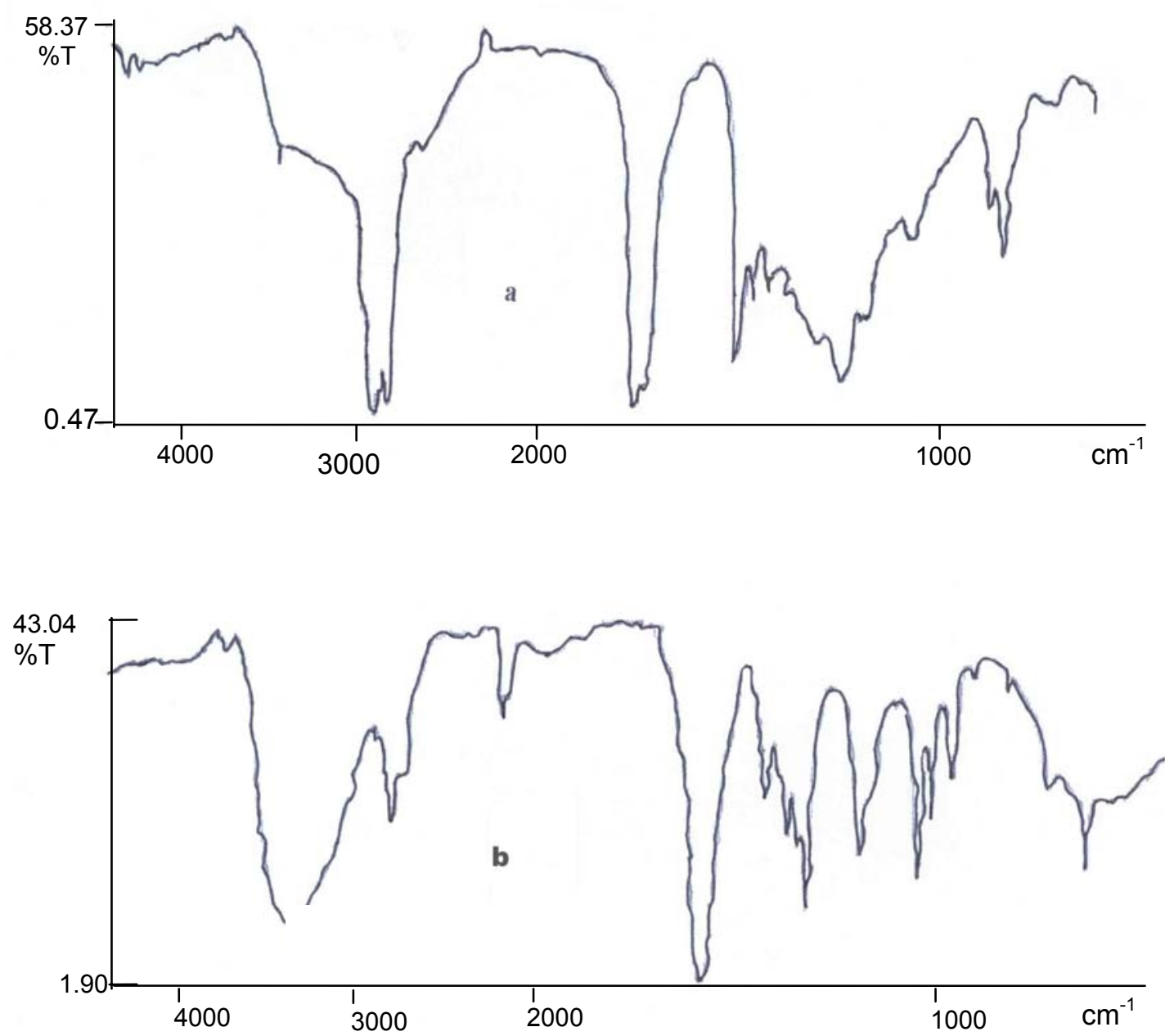

Gambar 7 Spektrum infra merah minyak hasil oksidasi (a) tanpa asetilasi, (b) dengan asetilasi.

\section{$4 \quad$ Kesimpulan}

Minyak jarak dengan kualitas yang lebih baik dari yang dihasilkan oleh standar AOAC telah diperoleh, dengan rendemen sebesar $45-48 \%$ per gram biji jarak. Minyak tersebut mengandung asam resinoleat sebesar $37 \%$, lebih rendah dari asam oleat dan palmitat. Proses proteksi dengan asetilasi terhadap gugus hidroksi minyak jarak berlangsung dengan baik, yang ditunjukkan dengan naiknya nilai bilangan iod dan turunnya nilai bilangan hidroksi. Proses oksidasi berlangsung lebih efektif terhadap minyak yang terasetilasi dari pada tanpa asetilasi. Kelebihan konsentrasi oksidator akan mengubah produk menjadi 
senyawa baru yaitu aldehid dan asam karbosilat. Kondisi optimum dicapai pada saat konsentrasi oksidator $15 \%$, dengan nilai bilangan iod 33,093 $\mathrm{mg} / \mathrm{g}$ dan bilangan hidroksi $1280.438 \mathrm{mg} / \mathrm{g}$.

\section{Daftar Pustaka}

1. Annual Book of ASTM Standards, D961, Washington, D.C. (1976).

2. James A. D., CRC Handbook of Medicinal Herbs, CRC Press Inc., Florida, USA (1985).

3. Jayant, Word of Castor Oil, http:/www.Indialog.Com/Jayant/uses.htm (2003).

4. Vignolo, R \& Naughton, F., Castor: A New Sense of Direction Inform, Vol. 2, Number 8, August (1991), pp. 692-99.

5. Fessenden \& Fesenden, Organic Chemistry, Third Edition, Wadsworth, Inc, Belmont, California, USA (1986).

6. Trost B. T., Ian F. \& Steven V. L., Comprehensive Organic Synthesis, Selective, Strategy, and Efficiency in Modern Organic Chemistry, Volume 7 Oxidation, Pergamon Press, USA (1994).

7. Pierre L., Organic Reaction, Simplicity, and Logic, Wiley and Son, Singapore (1994).

8. Furmiss B. S. et al., Vogel's Textbook of Practical Organic Chemistry New Edition, Fifth Edition, Longman Scientific and Technical, Joh Wiley and Sons Inc., New York (1989).

9. L. S Kiong \& John H. P. T., Conversion of Anacardic Acid into Urushiol, J. Chem. Soc. Perkin, 1942-1952 (1978).

10. Demirtas I., Selective Protection of Hydroxyl and Sulfur Groups with Trtyls, Fifth International Electronics Conference on Shyntetic Organic Chemistry (ECSOC-5), http:/www. Mdpi.org/ecsoc-5.htm (2001).

11. David F., Oil and Fat in Official Methods of Analysis of AOAC International, 16 th Edition, volume II, USA (1995). 